\title{
Change Detection in Landuse/ Landcover of Abeokuta Metropolitan Area, Nigeria Using Multi-Temporal Landsat Remote Sensing
}

\author{
Adebayo, H.Oluwasegun, Otun.W.O and Daniel, I. Samuel \\ Department of Geography, Olabisi Onabanjo University, Ago-Iwoye, Ogun State, Nigeria.
}

Received: 2019-05-18 Accepted: 2019-07-29

\author{
Keywords: \\ Land use/ Land cover \\ Change detection, \\ Remote Sensing, \\ GIS \\ Abeokuta.
}

Corespondent Email: adebayooluwasegunhezekiah@ gmail.com

\begin{abstract}
This research paper examined the changes in land use/ land cover of Abeokuta, Nigeria between 1984 and 2015 using Multi-Temporal Landsat Remote Sensing paired with Geographic Information System (GIS) techniques. The evaluation of the trend, rate and magnitude changes was the objectives of this study. Five Landsat satellite images of different dates, i.e., Landsat Thematic Mapper (TM) of 1984, 2001, 2006, 2011 and 2015 with spatial resolution ranging from 15, 30 and 60metres were obtained from National Aeronautics Space Administration(NASA),United State Geological Survey Website and GIS facility of Sioux Falls Website and quantify the changes over a period of thirty-one (31) years. Supervised classification methodology was applied to the acquired multi-band raster imageries using maximum livelihood technique in ERDAS Imagine 9.3. The images of the study area were classified into three (3) classes namely; vegetation, water body and built-up area and were overlay with vector maps of the study area generated in ArcGIS 10. The results show that for the period of 31years (1984-2015), vegetation which covered $76.20 \%$ of the total area has decreased to $39.29 \%$, water body decreases from $6.63 \%$ to $1.89 \%$ while the built -up area which initially was $17.14 \%$ as at 1984 increased to $58.82 \%$. The study, however, recommended that there is a need for a timely Land use/ Land cover mapping of the entire Abeokuta and its environs in order to reduce the effects of undiscrimate land utilization in the area. This will also facilitate necessary Land use planning and forestall the rising sprawl not only in Abeokuta but also in other urban centres.
\end{abstract}

(c) 2019 by the authors. This article is an open access article distributed under the terms and conditions of the Creative Commons Attribution(CC BY NC) licensehttps://creativecommons.org/licenses/by-nc/4.0

\section{Introduction}

Activities of man on earth surface has greatly revolutionised the natural environment, studies have shown that only a few landscapes are still in their natural state globally (Manish and Aruna, 2011). This had resulted into significant pattern in the changes of land use/land cover. Natural phenomena such as storms, wildfires, pest, earthquake, draught and the likes have also altered the form of natural land covers (Jwan et al., 2013). A state capital is usually the centre of development, Abeokuta which is a state capital in Nigeria, developing at an obvious rate has been a dreamland for people living in the peril-urban areas where there are fewer basic amenities and opportunity. The search for a better living has resulted into massive rural urban migration in the town. This result in pressure on social amenities, over-crowding, limited healthcare facility, increased crime rate due to limited job opportunities, atmospheric degradation, economic stability, increased waste generation, housing problem, traffic congestion and poverty. To reduce these environmental degradations in and around most cities in Nigeria, the technological advancement in relevant fields have to find a way around this menace caused by rapid urbanisation, only then development will be able to reach most of the deprived ones (Brandt and Townsend, 2006: Baja, 2007; Jwan et al., 2013). Demographic and the need to provide and maintain needs for sustainability and well-being of the people has made it important to examine the changes in land use/ land cover for the purpose of strategic and quantitative monitoring of natural resources and developments in the environments (Brandt and Townsend, 2006). Eludoyin et al. 2011 noted that the problem of disaster and unplanned development leads to deteriorating environmental quality. Land use /land cover change of an area in space is the outcome or as a result of natural and. socio-economic factors and how man make use of it in a particular time and space. Land use denotes how land and its resources are put to use by man including agriculture, urban development, grazing, logging and mining (Boyle et al., 2001; Jwan et al., 2013). While land cover on the other hand is use to describe the physical state of the land surface such has forest, crop lands, wetlands, arid land and water bodies (Brooks, 1999; Baskent et al., 2005; Jin et al., 2003). The use of aerial photography has been handy in the study of change in 
detection of land use/land cover before the invention of Remote Sensing and Geographic Information System (GIS) (Asiyanbola et al., 2014). Remote Sensing and Geographic Information System (GIS) are advanced methods in capturing, digitizing, analysing, processing and interpreting land use/land cover data. These two methods have enhanced the accuracy and authencity of land use/cover change analysis over period of time. Abeokuta being the capital of Ogun State and one of the urban centers in Nigeria had gone through tremendous developmental changes which include road expansion, deforestation, building of infrastructures and other human activities since its creation in 1976. The urban renewal for instance of the present Administration had revolutionised the landscape of the study area. These activities have resulted into the opening of some areas for major developments, increased land conversion which has altered and modified the landscape over time. So, there is need for comprehensive capturing and analysis of changes in the land use/land cover. Attempts were made in previous studies to model the change detection in land use/land cover of Abeokuta in the past (Ufoegbune et al., 2008), but due to recent extensive and massive land conversion in the study area, there is an urgent need for updating and having a comprehensive land use land cover data of the area using advanced GIS and Remote Sensing techniques. Therefore, the aim of this study is to examine the changes that have occurred to the land use/land cover of the study area over a period of 31 years, precisely $1984-2015$.

\section{The Methods}

The study area, Abeokuta (Figure.1), is located on latitude 709'39" N and longitude 30020'54" E. Abeokuta is the capital of Ogun State and one of the fastest growing urban centers in Nigeria. Bordered to the East by Ondo State and to the North by Oyo and Osun States respectively, it is bordered to the West by Republic of Benin and to the South by Lagos State. It is characterized by a hot humid climate $(280 \mathrm{C})$ with an average annual rainfall of $1.19 \mathrm{~m}$. The geology of basement complex of igneous and metamorphic origin; the metropolis covers a geographical area of 78.57 square kilometres (Gbadebo et al., 2010). The ancient and mythical historical background revolves around the Olumo Rock. The study area enjoys accessibility due to series of road network between it and other bigger cities. It is about $80 \mathrm{~km}$ north of Lagos. The relief, like other western parts of the country is characterized with geomorphic processes. The gently undulating plains are dotted with scattered rock outcrops, inselbergs and hills. The inselbergs and cuestas are mostly capped by concentration of aluminous calcareous, siliceous and ferruginous substances.

\section{Source of Data, Types and Processing}

Landsat -4 MSS of 1984, Landsat-5 TM of 2001, Landsat-7 ETM+ of 2006, Panchromatic ETM+ of 2011 and Landsat-7 ETM+ of 2015 Satellite Images with spatial resolution ranging from 15, 30 and $60 \mathrm{~m}$ were sourced from National Aeronautics and Space Administration (NASA), United States Geological Survey Website and GIS Facility of Sioux Falls Website and were used for the interpretation and in analyzing this work. Other data used as base maps such as topographic and administractive maps of Abeokuta were obtained from Ogun State Ministry of Work, Lands and Surveys, Nigeria.(Table1)

The data acquired were processed using ERDAS Imagine version 9.3, an image processing software to form a false colour composite for the study area using the layer stack option in the image interpreter tool box (Jin, 2003; Campbell, 2002). The sub-setting of the acquired satellite images was also carried out for extracting the study area from the images by georeferencing the boundary of Abeokuta. The following Indices such as normalized difference vegetation index (NDVI), normalized difference water index (NDWI) and normalized difference builtup index (NDBI) were also done to classify the Landsat images (Abuelgasim et al.,1999; Adu-prah et al., 2005). Also carried out was supervised classification through the

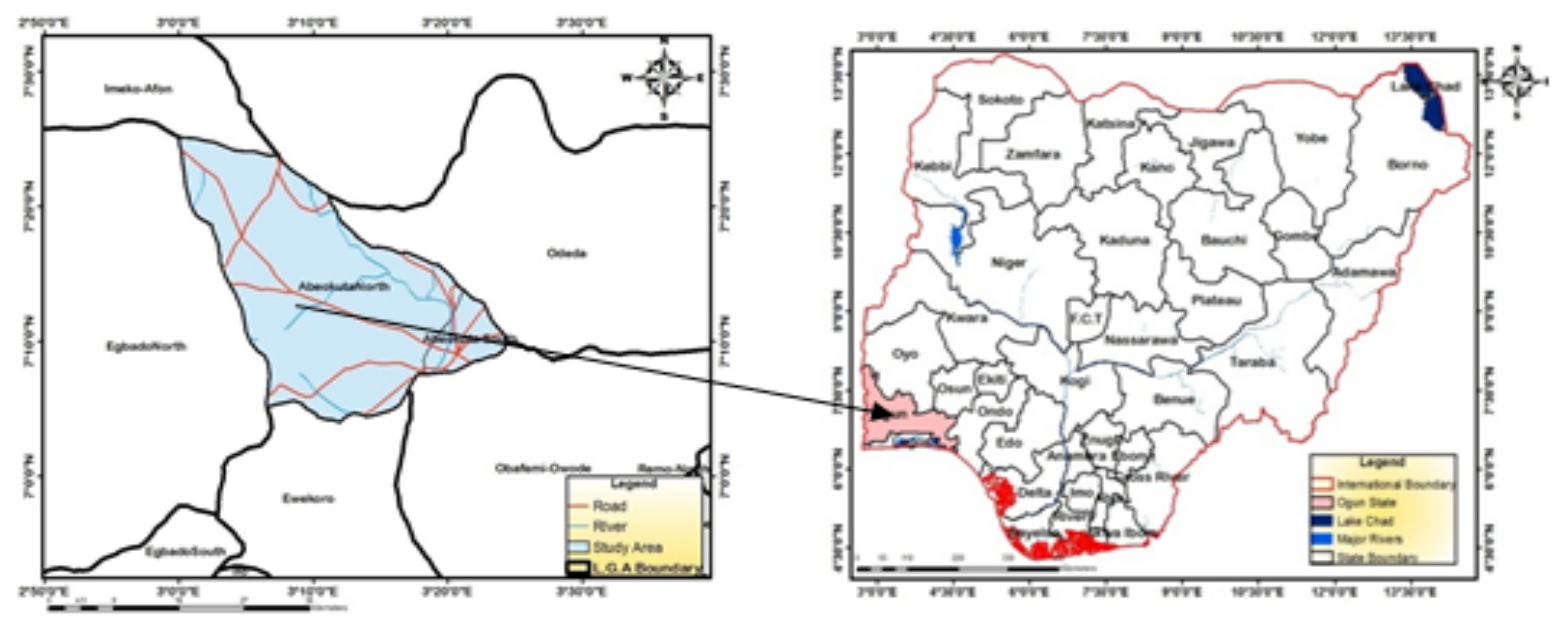

Figure 1. Map of the study area (Abeokuta) in Nigeria Context. 


\begin{tabular}{lcccc} 
& \multicolumn{2}{c}{ Table 1. Summary of Data Source } & & \\
\multicolumn{1}{c}{ Satellite } & Path/Row & Spatial Resolution & Year & Source \\
\hline LandSat-4 MSS & $190 / 55$ & 60 meters & 1984 NASA \\
Landsat-5 TM & $190 / 55$ & 30 meters & 2001 USGS \\
Landsat-7 ETM+ & $190 / 55$ & 30 meters & 2006 USGS \\
Panchromatic ETM+ & $190 / 55$ & 15 meters & 2011 Sioux Fals \\
Landsat-7 ETM+ & $190 / 55$ & 30 meters & 2015 USGS \\
\hline
\end{tabular}

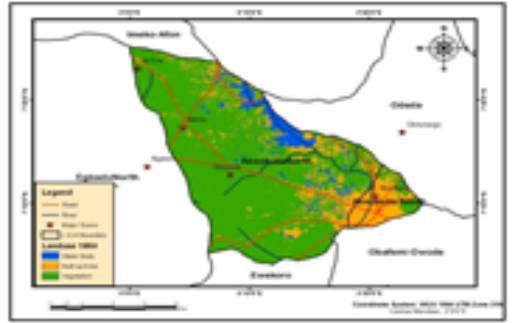

1984 Landuse/cover type classification

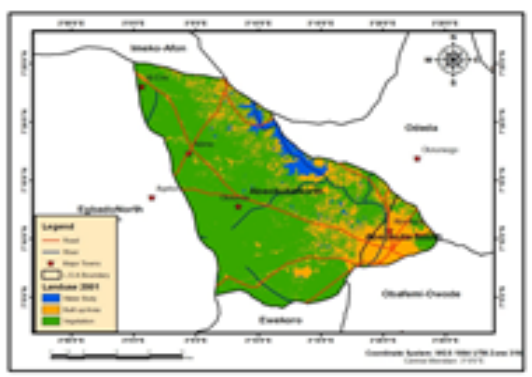

2001 Landuse/cover type classification

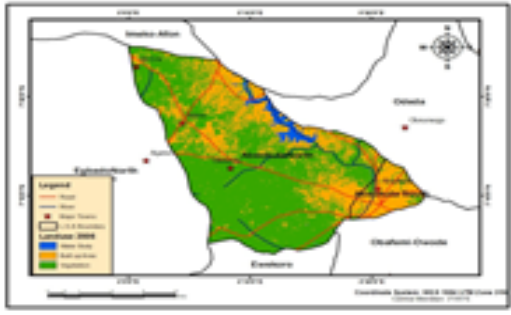

2006 Landuse/cover type classification

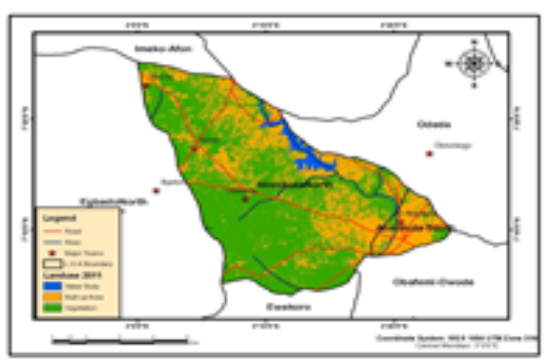

2011 Landuse cover type classification

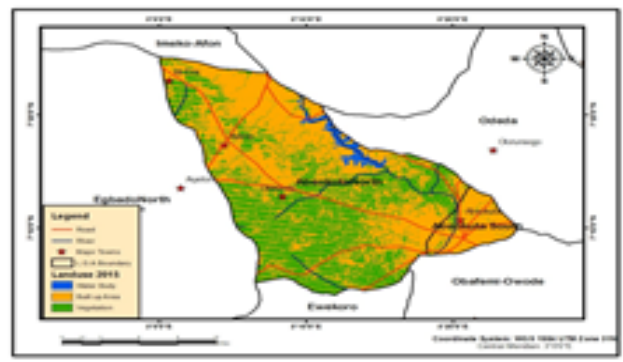

2015 Landuse/cover type classification

Figure 2. Land use/Land cover type classification maps of the study area between 1984 and 2015.

use of maximum likelihood algorithm in the ERDAS Imagine 9.3 Software (Campbell, 2002; Carreiras et al., 2006). Maximum likelihood algorithm is one of the most popular supervised classification methods used in processing sensored data (Rawat and Manish, 2015: Anderson et al., 1976; Baban et al., 2001). This method works on the assumption of probability where a pixel belongs to a particular class. These classes are assumed to have equal probabilities and that the input bands have normal distribution. However, this method has its own limitations which include; 1) computation is very slow and depend on a normal distribution of the data, 2) each input band tends to over-classify and relatively large 3) The spectral distance between the measurement vector for both candidate pixel and the mean vector for each signature is based on the equation for Euclidean distance.However,the pixels that should not be unclassified become classified and it does not consider class variability. Three (3) land use/cover type are identifed in the study area, i.e., vegetation, water body and built-up area. Calculation of the area of change detection in landuse landcover types of each period chosen for this study and sebsequent comparisons were carried out in square metre by using this expression, Percentage change (trend) equals dividing observed change by sum of changes multiplied 


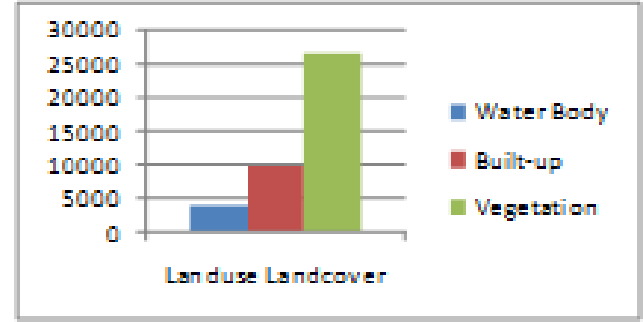

Bar chart showing land use land cover of Abeokuta for 1984

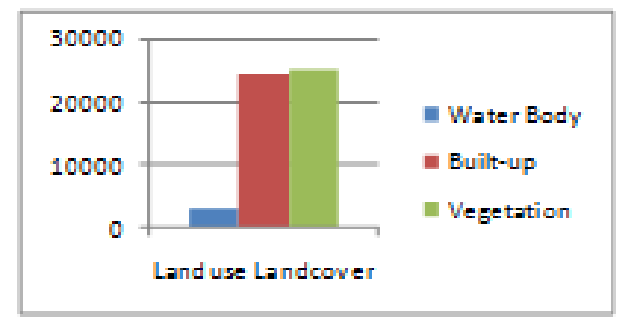

Bar chart showing land use land cover of Abeokuta for 2001

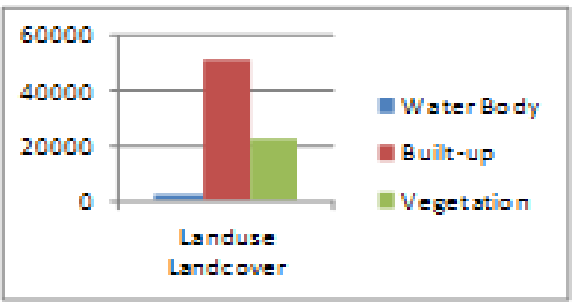

Bar chart showing land use land cover of Abeokuta for 2006

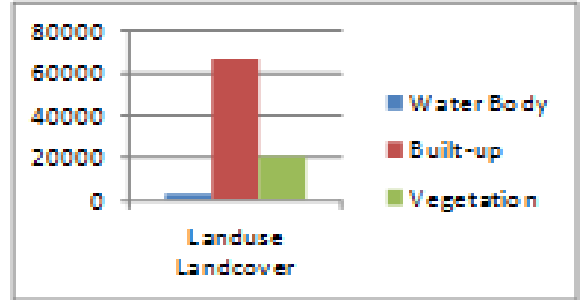

Bar chart showing land use land cover of Abeokuta for 2011

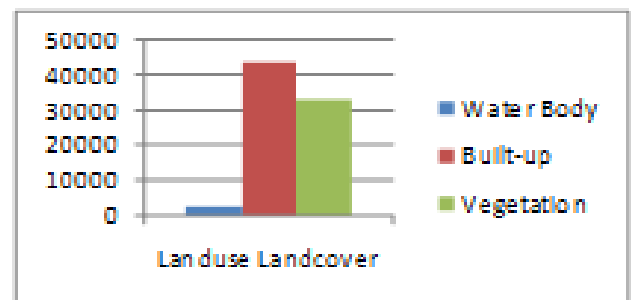

Bar chart showing land use land cover of Abeokutafor 2015

Figure 3. Bar Charts Showing the Pattern of Change in Land use Land cover of the study area (Abeokuta) for 1984, 2001, 2006, 2011 and 2015.

Table 2. Summary of Landuse/cover classification statistics of the study area.

\begin{tabular}{|c|c|c|c|c|c|c|c|c|c|c|}
\hline Period & \multicolumn{2}{|c|}{1984} & \multicolumn{2}{|c|}{2001} & \multicolumn{2}{|c|}{2006} & \multicolumn{2}{|c|}{2011} & \multicolumn{2}{|c|}{2015} \\
\hline $\begin{array}{l}\text { Landuse/ } \\
\text { cover type }\end{array}$ & $\mathrm{Ha}$ & $\%$ Area & $\mathrm{Ha}$ & $\%$ Area & $\mathrm{Ha}$ & $\begin{array}{c}\% \\
\text { Area }\end{array}$ & $\mathrm{Ha}$ & $\%$ Area & $\mathrm{Ha}$ & $\%$ Area \\
\hline $\begin{array}{l}\text { Water } \\
\text { Body }\end{array}$ & 5756.98 & 6.63 & 3544.17 & 4.08 & 2515.95 & 2.89 & 2267.64 & 2.61 & 1628.08 & 1.89 \\
\hline Built-up & 4876.60 & 17.14 & 17876.81 & 20.59 & 29717.37 & 34.23 & 28298.34 & 32.59 & 50728.54 & 58.82 \\
\hline Vegetation & 66160.69 & 76.20 & 65373.29 & 75.33 & 54587.7 & 62.88 & 56255.04 & 64.8 & 33886.55 & 39.29 \\
\hline Total & 86794.27 & 100 & 86794.27 & 100 & 86821.02 & 100 & 86821.02 & 100 & 86243.17 & 100 \\
\hline
\end{tabular}

Table 3. Changes in Landuse/Landcover between 1984 and 2001

\begin{tabular}{lll}
\hline Change Detected & Hectares & \% covered \\
\hline From V to W & 873.49 & 1.01 \\
From V to B & 2179.84 & 2.51 \\
No Change & 82348.5 & 94.88 \\
From B to V & 53.12 & 0.06 \\
From W to V & 1339.31 & 1.54 \\
& 86794.26 & 100 \\
\hline
\end{tabular}


Indonesian Journal of Geography, Vol. 51 No. 2, Agustus 2019 : 217 - 223

\begin{tabular}{lrr}
\hline \multicolumn{2}{c}{ Table 4.Changes in Landuse/Landcover between 2001 and 2006 } & \% covered \\
\hline \multicolumn{1}{c}{ Change Detected } & Hectares & 0.19 \\
\hline From V to W & 145.31 & 17.11 \\
From V to B & 13394.81 & 74.61 \\
No Change & 58423.92 & 1.35 \\
From W to B & 1054.3 & 0.42 \\
From W to V & 325.55 & 6.32 \\
From B to V & 4967.39 & 100 \\
\hline
\end{tabular}

Note: $\mathrm{V}=$ Vegetation, $\mathrm{W}=$ Water body, $\mathrm{B}=$ Built-up Area

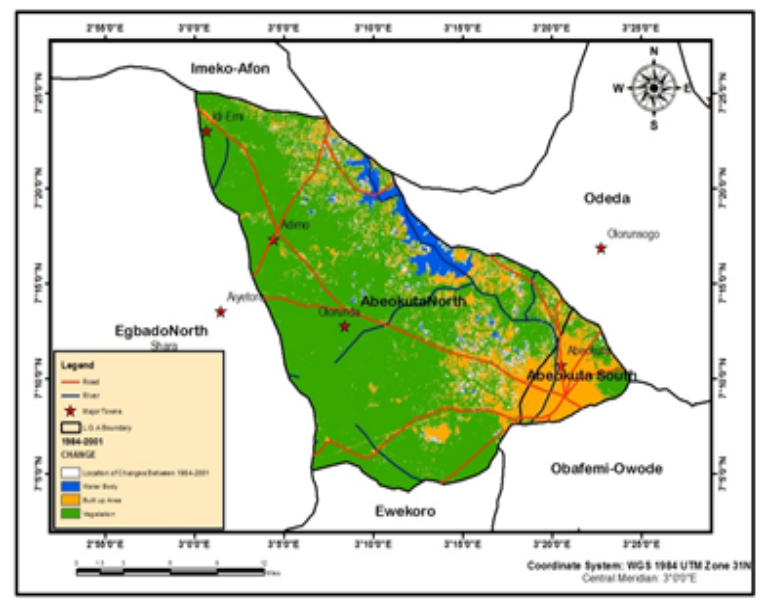

Figure 4. change in Landuse/Landcover from 1984 to 2001. Source: Derived from Landsat imageries of 1984 and 2001

by 100 , i.e., Percentage change $=$ Observed changes $/$ Sum of change x 100 (Anderson et al.,1976; Jin, 2003).

\section{Results and Discussion}

LandUse / Land Cover Classification/Distribution (1984-2015)

The change detection in landuse/ land cover for the different periods chosen for this study $(1984,2001$, 2006, 2011 and 2015) as derived from the Landsat Imageries acquired are shown in figure 2,3 and table 2 below. Results revealed that in 1984, Water body covers about 5756.98 ha (6.63\%). Built-up area is about 14876ha (17.14\%) while Vegetation covers 66160.69ha (76.2\%). By 2001, Water body had reduced to about $4.08 \%$ (3544.17ha). Built-up area sprang up towards the North-West direction of the study area by $20.59 \%$ (17876.81ha) and this eventually leads to reduction in the vegetation cover to $75.33 \%$ (65373.29ha of total land area compared to that of 1984 . Water body reduced to about $2.89 \%$ (2515.95ha) in 2006, Built-up area is on the high side by $34.23 \%$ (29717.37ha) and this eventually led to the reduction of vegetation cover to about $62.88 \%$ compared to that of 2001. Analysis further revealed that in 2011, there is a steady reduction of water body

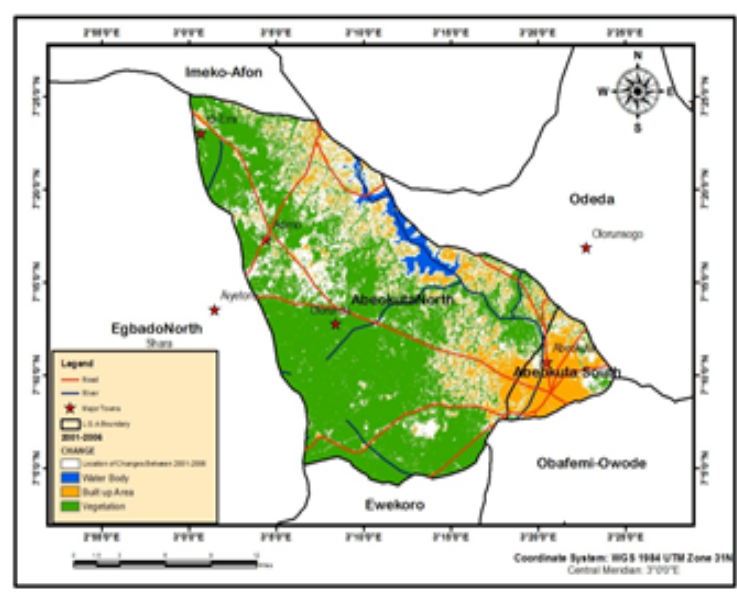

Figure 5. change in Landuse/Landcover from 2001 to 2006. Source: Derived from Landsat imageries of 2001 and 2006

to about $2.61 \%$ (2267.64ha). Built-up (32.59\%) kept increasing covering $32.59 \%$ just like in 2006 as a result of developments that kept increasing towards the North-East direction of the study area. By this time, the vegetation cover had reduced to 56255.04ha (64.8\%).

In 2015 , analysis shows that water body decreased to about $0.72 \%$ (1628.08hectares) but vegetation seems to have increased in some part of the study area to $39.29 \%$ while the built-up areas stood at $58.82 \%$ i.e. 50728 hectares of the total land area. This is as a result of mass demolition carried out during this period as part of urban renewal projects in the state.

Further more in this research work, the imageries of 1984,2001,2006,2011 and 2015 were evaluated and changes are summarized under four(4) periods.

\section{Changes in Landuse/Landcover from 1984-2001}

For the period of seventeen years(17), 94.8\% of land area covering about 82348.5 hectares experienced no significant change throughout this period except $2.51 \%(2179.84 \mathrm{ha})$ of vegetation cover that change to built-up area due to gradual development towards the north-east direction of the study area. Likewise, there was a slight change of $0.06 \%$ of built up area to 
Table 5. Changes in Landuse/Landcover between 2006 and 2011

\begin{tabular}{|c|c|c|}
\hline Change Detected & Hectares & $\%$ covered \\
\hline From $\mathrm{V}$ to $\mathrm{W}$ & 428.13 & 0.49 \\
\hline From $\mathrm{V}$ to $\mathrm{B}$ & 7846.38 & 9.04 \\
\hline No Change & 72270.18 & 83.24 \\
\hline From $\mathrm{W}$ to $\mathrm{B}$ & 6140.52 & 7.07 \\
\hline \multirow[t]{2}{*}{ From $\mathrm{W}$ to $\mathrm{V}$} & 135.81 & 0.16 \\
\hline & 86821.02 & 100 \\
\hline
\end{tabular}

Source: Derived from Landsat image of 2006 and 2011

Note: $\mathrm{V}=$ Vegetation, $\mathrm{W}=$ Water body, $\mathrm{B}=$ Built-up Area

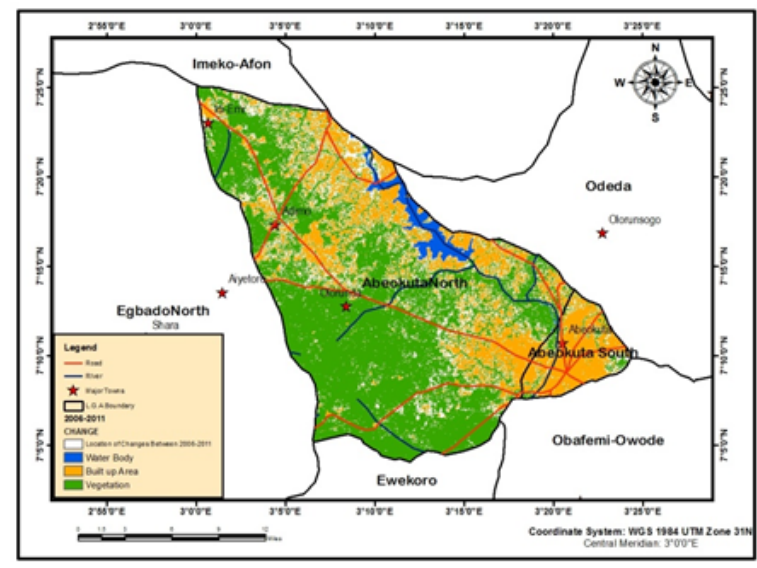

Figure 6. change in Landuse/Landcover from 2006 to 2011. Source: Derived from Landsat imageries of 2006 and 2011

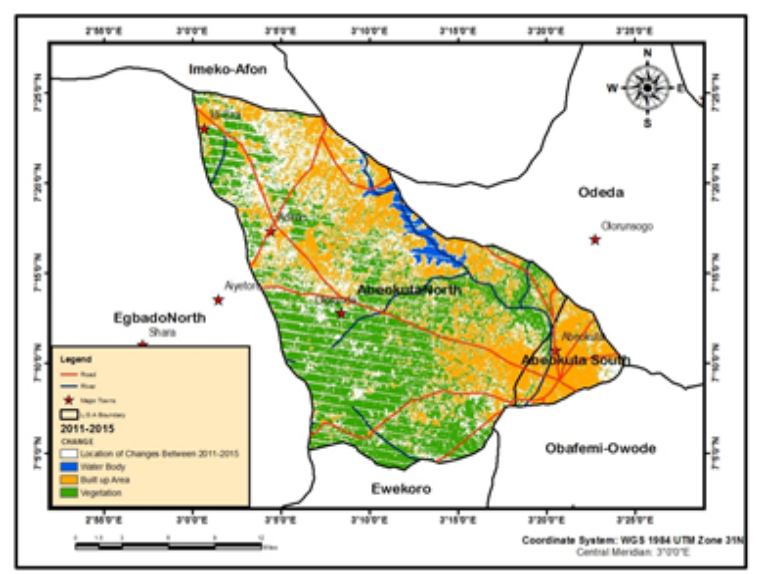

Figure 7. change in Landuse/Landcover from 2011 to 2015. Source: Derived from Landsat imageries of 2011 and 2015

vegetation due to abandoned buildings. there were also gradual changes of $1.54 \%$ of water body to vegetation cover as presented in Table 3 and Figure 4

\section{Changes in Landuse/Landcover from 2001-2006}

Within the space of five (5) years, there was a significant change of $17.11 \%$ (13394.81ha) of vegetation cover to built-up area with vegetation suffering more
Table 6. Changes in Landuse/Landcover between 2011 and 2015

\begin{tabular}{lll}
\hline $\begin{array}{l}\text { Change De- } \\
\text { tected }\end{array}$ & Hectares & \% covered \\
\hline From V to W & 15.66 & 0.02 \\
From V to B & 22974.21 & 26.46 \\
No Changes & 60470.55 & 69.65 \\
From W to B & 2467.98 & 2.84 \\
From W to V & 892.62 & 1.03 \\
& 86821.02 & 100 \\
\hline
\end{tabular}

Table 7. Changes in Landuse/Landcover between 1984 and 2015

\begin{tabular}{lll}
\hline Change Detected & Hectares & \% covered \\
\hline From V to W & 43.92 & 0.05 \\
From V to B & 34848.72 & 40.16 \\
No Changes & 49069.62 & 56.55 \\
From W to B & 2167.92 & 2.49 \\
From B to V & 641.34 & 0.75 \\
& 86771.52 & 100 \\
\hline
\end{tabular}

Source: Derived from Landsat images of 1984 and 2015

Note: $\mathrm{V}=$ Vegetation, $\mathrm{W}=$ Water body and $\mathrm{B}=$ Built-up Area

losses as people tends to build houses towards northeast direction again. $74.6 \%$ of the total land cover was left untouched. See table 4 and figure 5.

\section{Changes in Landuse/Landcover from 2006-2011}

Analysis shows that between 2006 and 2011 there seems to be a slight change of both vegetation(9.04\%) and water body (7.07\%) to built-up area compared to the changes experienced between 2001 and 2006. See table 5 and figure 6 below

\section{Change in Landuse/Landcover from 2011-2015}

Significant changes was experienced within this period with $26.46 \%$ (22974.21 ha) of the vegetation area along with water body $(2.84 \%)$ coverted to built-up areas. Vegetation cover $(0.02 \%)$ changed to water body while vegetation cover gained back $1.03 \%$ from the same water body. See table 6 and figure 7 . 


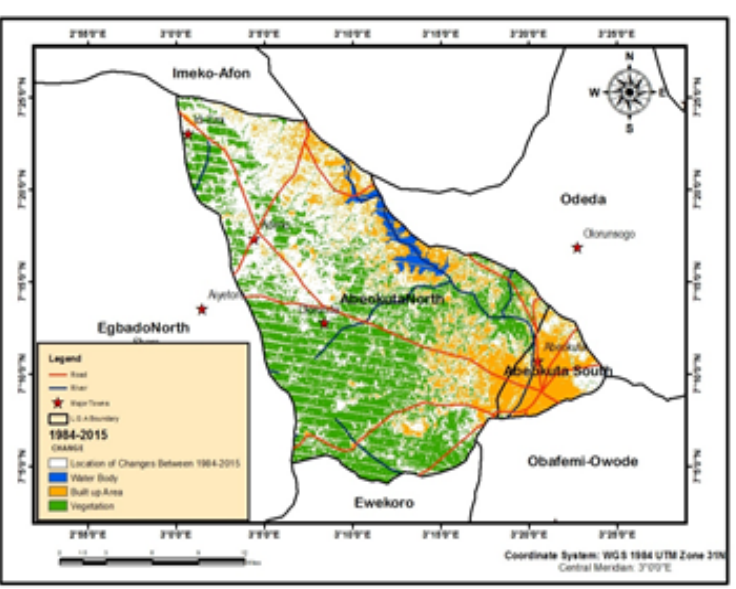

Figure 8 change in Landuse/Landcover from 1984 to 2015. Source: Derived from Landsat imageries of 1984,2001, 2006, 2011 and 2015.

\section{Change in Landuse/Landcover over Thirty-One(31) years i.e 1984-2015}

Between 1984 and 2015 as shown in table 7 and figure 8 below, about $40.2 \%$ of the vegetation cover along with $2.49 \%$ of water body changed to builtup areas while $0.05 \%$ of the total vegetation cover in the study area was converted to water body due to urban renewal projects embarked upon by the present administration in the state.

\section{Conclusion}

This work had demonstrated the ability of Remotely Sensed data paired with GIS techniques for capturing and analysis of spatial-temporal data. An attempt has been made to classify different landuse/landcover types and to classify them into three(3) broad classes using supervised classification. The research work has also attempted to explain the rate and magnitude of urban landuse/landcover changes between 1984 and 2015 also creating spatial data to explain all these changes. The result reveals that there were significant changes in landuse/landcover of Abeokuta(study area) over thirty-one(31) years i.e 1984 to 2015. There is a need for constant monitoring of these changes and to enhance a high level of compliance to the rules and regulations guiding the use of land in the study area.

\section{References}

Abuelgasim, A. A., Ross, W.D and Woodcock, C.E. (1999). Change detection using adaptive fuzzy neural networks. Remote Sensing of Environment 70(2): 208-223

Adu-Prah,S, Deidra,Y, and Rolanda, M. (2005). Integrating geospatial and temporal data for water quality monitoring in Southwest Mississippi. 31st International Symposium on Remote Sensing of Environment-Saint Petersburg.

Anderson, J. R., Hardy, E.E., Roach, J.T and Witmer, R.E. (1976). A land use and land cover classification for use with remote sensor data. USGS Professional Paper 964. Washington, DC: US Government Printing Office, 18 p.
Asiyanbola R.A, Adebayo O.H, Otun W.O, Raji B.A and Osibodu O.G. (2014). Remote Sensing and Geographic Information System for inferring Land cover and Land use Changes in Ibadan, Nigeria (1984-2013). International Journal of Ecology and Environmental Studies, 2(1): 63-80.

Baban, M.J. and Kamaruzaman W. Y. (2001). Mapping land use/cover distribution on a mountainous tropical island using remote sensing and GIS.International Journal of Remote Sensing 22(10):1909-1908.

Baja, S, David, M.C and Deirdre D. (2007). Spatial based compromise programming for multiple criteria decision making in land use planning. Environmental Model Assessment 12: 171-184.

Baskent, E. Z., Kose, S and Keles, S (2005). The forest management planning system of Turkey: Constructive criticism towards the sustainable management of forest ecosystems. International Forest Review 7 (3): 208-217.

Boyle, S. J., Tsanis, I.K and Member, E.D. (2001). Developing Geographic Information Systems for Land Use Impact Assessment in Flooding Condition. Journal of Water 6Resources Planning and Management 89-97.

Brandt, J. S. and Townsend, P.A. (2006). Land use/ land cover conversion, regeneration and degradation in the high elevation Bolivian Andes. Landscape Ecology 21 (4):607-623.

Brooks, K. N. (1991). Hydrology and the management of watersheds. Iowa: Iowa University Press.

Campbell, J. B. (2002). Introduction to remote sensing. New York: The Guilford Press

Carreiras, J, Jose, M.B., Pereira, M.C and Yosio, E.S. (2006). Land-cover Mapping in the Brazilian Amazon Using SPOT-4 Vegetation Data and Machine Learning Classification Methods. Photogrammetric Engineering \& Remote Sensing897-910.

Eludoyin, O.S., Wokocha, C.C., and Ayolagbo, G., (2011). GIS Assessment of Land Use and Land Cover Change in OBIO/AKPOR L.G.A., Rivers State, Nigeria. Maxwell Scientific Organization. Research Journal of Environmental and Earth Sciences 3(4): 307-313.

Gbadebo, A.M., Oyedepo, J.A and Taiwo A.M.. (2010)."Variability of Nitrate in Groundwater in Some Parts of Southwestern Nigeria". The Pacific Journal of Science and Technology.11 (2): 572-584.

Jin, C, PengGong, C. H., Ruiliang, P and Peijun, S (2003). Land-use/ Land-cover Change Detection Using Improved Change-Vector Analysis. Photogrammetric Engineering \& Remote Sensing, 69(4): 369-379.

Jwan, A, Shattri, B. M and Helmi, Z S. (2013). Change Detection Process and Techniques. Civil and Environmental Research, 3(10): 37-45.

Manish, K.T. and Aruna, S (2011), Change Detection of Land use/ Land cover Pattern in an Around Mandideep and Obedullaganj Area, Using Remote Sensing and GIS. International Journal of Technology and Engineering System (IJTES), 2(3):342-350. 